\title{
Strategi Group Investigation dalam Pembelajaran Mahārat al-Qirāăh pada Mahasiswa Jurusan Bahasa dan Sastra Arab, UIN Maulana Malik Ibrahim, Malang
}

\author{
Amalia H. Islamiyah*, Muassomah \\ Universitas Islam Negeri (UIN) Maulana Malik Ibrahim, Malang, Indonesia
}

\section{Group Investigation Strategy in Learning Mahärat al-Qirāăh to the Students of the Arabic Language and Literature Department at UIN Maulana Malik Ibrahim, Malang}

\section{E-Mail Address}

amaliahislamiyah64@gmail.com

${ }^{*}$ Corresponding Author

\section{Keywords}

Mahārat al-qirāà ;

group investigation;

language learning strategy

\begin{abstract}
In learning reading skills (mahārat al-qiräả $)$, especially Arabic texts, students are required to be able to reach existing indicators, which are at the level of critical reading. One effort to foster a critical attitude is to implement a group investigation strategy in the learning process. Therefore, the purpose of this study is to see how far the effectiveness of applying the group investigation strategy in learning mahārat al-qirā'ah 2 to the students of Arabic Language and Literature Department, UIN Maulana Malik Ibrahim. The results of this study prove that the application of the group investigation strategy applied in learning mahärat al-qirä'ah 2 can make students active and critical in analyzing discourse. The obstacle is the lack of student commitment to time so that the learning seems rushed. The solution, students are accustomed to reading Arabic texts so that they are familiar with new mufradāt (vocabulary), and commitment to the time given by lecturers so that learning is more effective and efficient.
\end{abstract}

\section{Pendahuluan}

Pembelajaran keterampilan membaca (mahārat al-qirāaha) di jenjang perguruan tinggi, selain mampu membaca teks Arab sesuai dengan naḥwu dan șaraf, juga masuk dalam ranah membaca pemahaman (comprehension skills) dan membaca kritis (critical reading) (Fitriani, 2018, p. 4). Kenyataannya, kegiatan proses belajar mengajar pada keterampilan membaca di Universitas Islam Negeri (UIN) Maulana Malik Ibrahim Malang selama ini masih banyak permasalahan yang dihadapi oleh mahasiswa. Di antaranya, dalam menentukan ide pokok, gagasan utama, dan kurang tepat dalam menjawab pertanyaan, padahal mahasiswa telah membaca teks atau wacana yang ditugaskan dosen. Begitu pun, ketika ditanya terkait isi dari bacaan atau teks, mahasiswa ragu dan bahkan tidak bisa menjawab. Selain itu, penerapan pembelajaran dalam kelas yang monoton, misalnya penggunaan strategi, metode, maupun teknik yang kurang bervariasi, membuat mahasiswa kurang semangat dan 
aktif dalam proses pembelajaran. Oleh karena itu, penelitian ini memberikan solusi dengan menerapkan strategi group investigation dalam pembelajaran mahārat al-qirāàh. Strategi ini mendorong siswa lebih berfikir kritis, kreatif, dan membangun kerjasama yang baik sehingga pembelajaran lebih efektif dan efisien.

Penelitian tentang pembelajaran mahārat al-qirä'ah, baik itu terkait dengan metode maupun strategi yang digunakan, misalnya, dilakukan oleh Ach. Sholehuddin \& Mu'allim Wijaya (2019). Penelitiannya terkait dengan penerapan metode Amtsilati dalam meningkatkan kemampuan mahārat al-qirāa'ah di asrama wilayah K Pondok Pesantren Nurul Jadid, Paiton, Probolinggo. Penelitian ini menunjukkan bahwa penerapan metode Amtsilati mampu meningkatkan keterampilan mahārat al-qirā'ah santri. Ini dibuktikan dengan adanya santri yang awal mulanya benar-benar berangkat dari nol, namun setelah menyelesaikan Amtsilati mereka dapat membaca teks berbahasa Arab terlebih lagi kitab kuning. Selain itu, dalam penerapan strategi group investigation juga banyak dilakukan. Satu di antaranya adalah Dzikrul Hakim, dkk (2018) dalam penelitiannya tentang penggunaan strategi group investigation dalam meningkatkan kemampuan siswa dalam menerjemahkan bahasa Arab ke bahasa Indonesia. Hasil dari penelitian kuantitatif ini adalah, strategi group investigation dapat meningkatkan kemampuan terjemah siswa dengan baik, namun kurang efektif. Ada perbedaan antara hasil belajar siswa yang menggunakan strategi group investigation dengan siswa yang tidak menggunakan strategi group investigation. Selain itu, Rafnelli Syuhaimi (2019) juga melakukan penelitian tentang penerapan model pembelajaran group investigation dalam meningkatkan minat dan keterampilan pada pelajaran bahasa Inggris, khususnya reading comprehension siswa kelas IXA di MTs N Kampar. Hasil penelitian tersebut menunjukkan bahwa dengan model pembelajaran group investigation, hasil keterampilan reading comprehension peserta didik meningkat. Ini terlihat dari hasil akhir pertemuan siklus 1 sebanyak 36,4\% yang tuntas secara klasikal, dan pada akhir pertemuan siklus 2 menjadi $77,3 \%$.

Dari hasil studi pendahuluan tersebut, penelitian ini bertujuan untuk melengkapi penelitian yang sudah dilakukan oleh para peneliti sebelumnya. Peneliti menerapkan strategi ini dalam pembelajaran keterampilan membaca (mahārat al-qirā̄ah 2) yang diterapkan pada mahasiswa Jurusan Bahasa dan Sastra Arab UIN Maulana Malik Ibrahim, Malang. Tujuannya untuk mengetahui pembelajaran mahārat al-qirā'ah 2 yang dilakukan selama ini, mengetahui bentuk penerapan strategi group investigation dalam pembelajaran mahārat al-qirāàah 2, dan untuk mengetahui hasil dari penggunakan strategi group investigation pada pembelajaran mahārat alqiräah 2. Untuk menjawab tujuan tersebut, penelitian ini memiliki tiga rumusan masalah yang menjadi pertanyaan, yaitu: (1) bagaimana pembelajaran mahārat al-qirāa a 2 di Jurusan Bahasa dan Sastra Arab UIN Maulana Malik Ibrahim, Malang? (2) bagaimana penerapan strategi group investigation dalam pembelajaran mahārat al-qirāa'ah 2? dan (3) bagaimana hasil proses pembelajaran dengan menggunakan strategi group investigation pada pembelajaran mabārat alqirā'ab 2?

Penelitian ini memberikan asumsi bahwa dengan adanya penerapan strategi group investigation dapat meningkatkan motivasi dan semangat mahasiswa dalam mengikuti proses belajar dan mengajar di kelas. Metode ini menawarkan beberapa tahapan dalam proses pembelajaran, di antaranya melalui kegiatan pembagian kelompok secara heterogen, diskusi bersama dalam kelompok kecil, dan mempresentasikan laporan di depan kelas, serta adanya interaksi atau tanya jawab di antara kelompok. Dengan demikian, melalui beberapa tahapan tersebut, selain membangun kerjasama yang 
baik di antara mahasiswa, juga dapat membentuk pemahaman terkait kemampuan berfikir kritis. Melalui strategi ini, mahasiswa digiring dan diarahkan melalui langkah-langkah kerja group investigation dengan bingkai pendekatan kritis dalam kegiatan berkelompok. Selain itu, itu mahasiswa bisa saling menukar informasi terkait dengan topik yang dibahas, dalam hal ini informasi terkini melalui tema wacana jurnalistik. Tujuannya, melalui berbagai macam step yang diberikan melalui strategi ini, pembelajaran mabārat al-qirāàh 2 akan tercapai secara maksimal, dan pembelajaran di kelas juga menjadi lebih efektif dan efisien.

\section{Landasan Teori}

\section{A. Keterampilan Membaca (Mahāratal-Qira'ah)}

Membaca adalah salah satu dari empat keterampilan bahasa yang paling penting. Dua aspek dari sisi otomatisnya adalah untuk mengidentifikasi bentuk huruf dan suara mereka, dan kemampuan untuk membentuk kata-kata dan kalimat. Selain itu, dari sisi pengetahuan mengarah pada pemahaman materi bacaan ('Abd al-Majīd, 2005, p. 17). Membaca dapat dikatakan sebagai salah satu keterampilan yang unik dan memainkan peran penting dalam mengembangkan ilmu pengetahuan, serta menjadi alat komunikasi dalam kehidupan masyarakat. Dikatakan unik karena tidak semua manusia mampu mengembangkan kemampuan atau keterampilan membacanya menjadi suatu alat yang mampu memberdayakan diri sendiri. Selain itu, dibutuhkan usaha yang lebih untuk membentuk suatu keahlian. Kemampuan membaca juga menjadi penting karena persentase transfer pengetahuan tertinggi adalah melalui membaca. Contoh, di Jepang, masyarakat memiliki kebiasaan membaca yang tinggi (Mustofa, 2014, p. 134). Oleh karena itu, kemampuan membaca perlu dibangun melalui berbagai macam kegiatan, baik itu melalui strategi pendekatan ataupun media yang mendorong keinginan untuk membiasakan diri membaca, serta komitmen yang mendalam untuk terbiasa membaca.

Membaca juga merupakan kegiatan yang didasarkan pada kolaborasi berbagai keterampilan, yakni proses mengamati, memahami, dan memikirkan (Nopitaningrum, 2019, p. 2). Adanya kolaborasi bertujuan untuk mencari atau memeroleh informasi, mencakup isi maupun memahami suatu bacaan (Hermawan, 2013, p. 143). Suksesnya seorang pembaca adalah ketika ia memiliki kemampuan. Kemampuan dalam artian mampu untuk menempatkan serta menyesuaikan kata berdasarkan arti leksikal dan kesesuaian tata bahasa untuk memeroleh makna. Selain itu, juga menggunakan berbagai cara untuk memeroleh tujuan yang berbeda pula, sehingga mampu mengaitkan antara isi teks dengan latar belakang pengetahuannya terhadap apa yang dibacanya, serta menentukan makna retorika atau fungsi dari kalimat dari teks yang ada (Hidayah, 2019, p. 105). Kemampuan dalam membaca juga memiliki beberapa tingkatan, di antaranya, yaitu kemampuan membaca literal, interpretatif sampai kemampuan membaca kritis sehingga membutuhkan adanya pembiasaan untuk mencapai tingkatan kemampuan membaca tertinggi.

Penelitian tentang dengan keterampilan membaca (mahārat al-qirāàh) telah banyak dilakukan, di antaranya oleh Anwar Abd. Rahman (2017), terkait dengan keterampilan membaca dengan teknik pengembangannya dalam pembelajaran bahasa Arab. Dalam penelitian ini juga ditawarkan strategi, media, teknik yang bisa diterapkan dalam pembelajaran mahārat al-qirā'ah. Laili Fitriani (2019), di sisi lain, terkait dengan pembelajaran keterampilan membaca berasaskan membaca kritis yang diterapkan pada mahasiswa Bahasa dan Sastra Arab UIN Maulan Malik 
Ibrahim Malang. Tujuannya agar mahasiswa mampu berfikir kritis terhadap bacaan yang ada. Penelitian lainnya juga dilakukan oleh Ni Putu Yuliantika, dkk (2018) terkait dengan penggunaan strategi directed reading thinking activity (DRTA) dalam reading comprehension. Dengan membandingkan dua strategi yang diterapkannya, penelitian tersebut menunjukkan hasil bahwa strategi group investigation ini lebih tinggi dibandingkan dengan penggunaan strategi konvensional dalam pembelajaran reading comprehension. Adanya penelitian-penelitian tersebut sangat membantu sekaligus menjadi jalan para pendidik dalam mengembangkan ide secara kreatif dan inovatif untuk merealisasikan tujuan pembelajaran mahārat al-qirā'ah.

\section{B. Strategi Pembelajaran}

Menurut Suja'i (2008), strategi dalam pendidikan terdapat dua sudut pandang, yaitu secara makro dan mikro. Secara makro, strategi memiliki arti bahwa pengambilan keputusan yang mendasar dalam pengembangan pendidikan untuk mencapai tujuan pendidikan secara terarah, efektif dan efisisen. Adapun secara mikro dalam operasional pembelajaran, strategi merupakan sebuah aksi mendasar yang memiliki andil penting dalam proses pembelajaran untuk mencapai tujuan yang telah ditetapkan, misalnya proses belajar dan mengajar bahasa Arab. Jadi, dapat disimpulkan bahwa strategi pembelajaran merupakan seperangkat rencana, aturan, dan langkah yang digunakan dalam proses pembelajaran. Adanya strategi sangat membantu para pendidik untuk merealisasikan tujuan sehingga pembelajaran pun bisa terarah efektif dan juga efisisen. Sementara itu, strategi pembelajaran bahasa yaitu penerapan rencana dalam proses pembelajaran bahasa untuk mencapai tujuan, yang dalam hal ini terdiri dari dua aspek. Pertama, terkait dengan unsur bahasa seperti așwāt, mufradāt, dan tarākib. Kedua, yang berkaitan dengan keterampilan bahasa, di antaranya istimā́ , kalām, qirā'ah, dan kitäbah (Musthafa \& Hamid, 2012, p. 67).

Menurut Syaiful Bahri Djamarah \& Aswan Zain (2006), terdapat empat strategi dasar dalam praktik pembelajaran, yaitu: (1) menetapkan spesifikasi dan kualifikasi adanya perubahan tingkah laku serta kepribadian setiap anak didik; (2) memilih sistem pendekatan dalam pembelajaran berdasarkan harapan dan tujuan keberhasilan di masa yang akan datang; (3) pandangan hidup masyarakat, menetapkan prosedur, metode, dan teknik yang dianggap paling tepat dan efektif, sehingga dapat dijadikan pedoman para guru dalam merealisasikan kegiatan mengajarnya; dan (4) menetapkan norma dan kriteria standar keberhasilan sebagai acuan guru dalam melakukan penilaian hasil kegiatan pembelajaran, serta dijadikan feedback dalam menyempurnakan sistem instruksional secara menyeluruh. Sementara itu, menurut Suja'i (2008), tiga kelompok strategi pembelajaran bahasa Arab, yaitu: (1) al-istirātījīyāh al-ma'rifíyah al-munawarah, yaitu meliputi perencanaan pembelajaran, pendapat tentang proses belajar, pengontrolan hasil belajar, dan evaluasi; (2) alistirātijizyāh al-ma'rifíyah, yaitu konsep yang berkaitan dengan kewajiban penanganan secara langsung dalam pemerolehan materi; dan 3) al-istirātījīyāh al-ijtima'îyah al-wujdānìyah, yaitu strategi berkaitan dengan interaksi sosial.

Terkait dengan strategi pembelajarannya bahasa Arab, di antaranya penelitian yang dilakukan oleh Asbullah, dkk (2019), terkait dengan penggunaan strategi pembelajaran kolokasi bahasa Arab dan penerapannya pada para pelajar di Universiti Awam Malaysia. Strategi kolokasi merujuk pada keterkaitan posisi atau keberadaan antara satu dan lain dari perkataan dalam satu susunan. Kolokasi ini dianggap penting karena mampu meningkatkan kecakapan seseorang dalam bertutur. Penelitian lainnya, Nicky Nihayatun Nisa, dkk (2019) tentang pengubahan metode qawā'id wa-al-tarjamab 
dengan menggunakan strategi contextual teaching and learning (CTL) dalam penerapan pembelajaran keterampilan menulis. Penelitian ini memadukan antara metode qawāid wa-altarjamab dengan strategi contextual teaching and learning (CTL) dalam menciptakan pembelajaran yang lebih komunikatif dan aplikatif dalam pembelajaran mahārat al-kitābah. Begitu pula, penelitian yang dilakukan oleh Ulin Nuha (2018) tentang permainan "treasure bunt" sebagai sebuah strategi pembelajaran bahasa Arab. Strategi ini dapat meningkatkan kemampuan mendengar, berbicara, membaca dan menulis, melalui pembelajaran yang enjoy dan menyenangkan.

\section{Group Investigation}

Satu dari sekian banyak model pembelajaran kooperatif (cooperative learning) adalah group investigation atau investigasi kelompok. Terbentuk dari dua kata, yaitu group dan investigation. Group berarti kelompok atau golongan, dan investigation berarti penyelidikan (Poerwadarminta, 1980, p. 71). Dari sini dapat dipahami melalui pembentukan dua kata tersebut bahwa group investigation memiliki pengertian sekumpulan orang yang memiliki tujuan tertentu melalui kerjasama yang baik untuk melakukan analisis dengan sungguh-sungguh terhadap sutu obyek dalam waktu tertentu. Strategi ini dikembangkan di University of Tel Aviv (Sharan \& Shacar, 1988). Model pembelajaran kooperatif tipe group investigation merupakan model pembelajaran kooperatif yang mendorong serta memacu peserta didik atau pembelajar untuk berpikir secara kritis, kreatif, dan analitis (Aini et al, 2018, p. 19). Investigasi kelompok ini merupakan sebuah rencana dengan menggunakan strategi inquiry, yaitu para peserta didik bekerjasama dengan membentuk kelompok kecil. Kemudian, memilih topik dari mata pelajaran dan mengklasifikasikannya berdasarkan bagian tema yang merupakan tugas masing-masing individu, serta menyajikan sebuah laporan untuk dipaparkan di depan kelas (Hakim et al: 2018, pp. 81-84).

Sebagai salah satu tipe dalam pembelajaran kooperatif, group investigation didefinisikan sebagai model pembelajaran yang mengikutsertakan siswa secara aktif dalam membentuk kelompok yang terdiri atas 3-6 orang untuk melakukan perencanaan, kemudian penyelidikan, serta membuat sintesis temuan. Kegiatan akhirnya yaitu mengomunikasikan hasil temuannya secara bergantian di depan kelas dengan berkelompok. Dengan begitu, yang menjadi kelebihan dari salah satu tipe dari pembelajaran kooperatif ini adalah siswa tidak terlalu menggantungkan pembelajaran kepada guru, melainkan mampu menambah kepercayaan terhadap kemampuan berfikir sendiri, berfikir kreatif dan inovatif dalam menemukan informasi dari berbagai sumber dan belajar dengan siswa lain, serta saling mentransfer ilmu pengetahuan. Selain itu, menuntut untuk saling bekerja sama antara peserta didik, mengurangi adanya ketakutan dan ketidakpercayaan diri dalam menyampaiakan argumentasi. Siswa juga mampu berinteraksi dengan baik antarsesama anggota kelompok lainnya tanpa memandang latar belakang sehingga setiap individu memiliki sumbangsih atau keikutsertaan dalam menemukan solusi (Sakinah \& Purwanto, 2019, p. 2).

Penelitian terkait dengan group investigation juga telah banyak dilakukan, di antaranya penelitian yang dilakukan oleh Delia Putri (2018), terkait penggunaan strategi group investigation dalam keterampilan menulis berita. Melalui strategi ini dapat meningkatkan hasil keterampilan menulis berita mahasiswa. Di sisi lain, penelitian Suci Marselina (2018) terkait dengan peningkatan keterampilan menulis karya ilmiah dengan menggunakan strategi group investigation. Tujuannya dengan menggunakan strategi ini dapat menjadi solusi dari permasalahan yang ditemukan siswa dan 
guru, sehingga dapat meningkatkan keterampilan siswa dalam menulis karya ilmiah. Selain itu, juga terdapat penelitian yang dilakukan oleh Komang Adia (2019) tentang penerapan model pembelajaran tipe group investigation untuk meningkatkan hasil belajar pada pelajaran simulasi digital di SMK Negeri 1 Sukasada. Beberapa penelitian tersebut merupakan contoh dari penggunaan strategi group investigation yang diterapkan pada berbagai macam pelajaran. Oleh karena itu, dapat dikatakan bahwa strategi ini efektif dan mudah diterapkan pada berbagai jenis mata pelajaran jika dipraktikkan dengan baik, kemudian disesuaikan dengan karakteristik setiap materi dan juga langkah-langkah strategi ini.

\section{Metode Penelitian}

Lokasi penelitian bertempat di Jurusan Bahasa dan Sastra Arab, Fakultas Humaniora, UIN Maulana Malik Ibrahim, Malang, Jl. Gajayana No.50, Dinoyo, Kec. Lowokwaru, Kota Malang, Jawa Timur 65144. Jurusan Bahasa dan Sastra Arab dipilih karena salah satu mata kuliahnya adalah mahārat alqira'ah 2, khususnya pada semester 3. Mata kuliah mahārat al-qirä'ah 2 ini masih membutuhkan perhatian dari aspek penggunaan strategi, metode, maupun media pembelajarannya. Pembelajaran mahārat al-qirāà 2 selama ini hanya sebatas membaca, menerjemahkan, tanya jawab bersama dosen, membaca kreatif, dan lain sebagainya. Oleh karena itu, dibutuhkan inovasi baru dalam pembelajarannya, baik itu melalui strategi, metode, teknik, maupun media. Dengan begitu, inovasi tersebut dapat merealisasikan tujuan dari keterampilan membaca sehingga proses pembelajaran lebih interaktif antarsesama mahasiswa.

Metode dan pendekatan yang digunakan dalam penelitian ini adalah metode penelitian deskriptif dengan pendekatan kualitatif. Penelitian ini terdiri dari data kualitatif dengan tujuan untuk mendeskripsikan pembelajaran mahārat al-qirāah, langkah-langkah penerapan model pembelajaran dengan menggunakan strategi group investigation, dan hasil yang diperoleh ketika dipraktikkan dalam pembelajaran mahārat al-qirā'ah 2 pada mahasiswa semester 3 Jurusan Bahasa dan Sastra Arab. Dengan demikian, dapat dilakukan evaluasi terkait pembelajaran mahārat alqirä $a h$, dan tindak lanjut dalam merencanakan pembelajaran ke depannya.

Sumber data dalam penelitian ini adalah observasi, yakni dengan melakukan observasi mendalam terhadap proses belajar mengajar mahärat al-qirāàh. Peneliti melakukan observasi sebelum penerapan group investigation, pada saat penerapan strategi group investigation, dan setelah penerapan strategi group investigation. Kemudian, peneliti juga menggunakan wawancara yang bertujuan untuk menggali data tentang motivasi mahasiswa dalam proses belajar mengajar dengan menggunakan strategi group investigation. Dalam wawancara, peneliti menggunakan singkatan " $\mathrm{S}$ " sebagai pengganti nama informan. Peneliti menggunakan wawancara kepada seluruh mahasiswa di kelas dengan menggunakan metode tertulis. Terakhir, penelitian ini juga menggunakan data dokumentasi. Melalui dokumentasi diperoleh data hasil mahasiswa dalam penerapan strategi group investigation. Dokumen ini terdiri dari beberapa alat untuk menilai keberhasilan mahasiswa. Peneliti akan menemukan fakta atau data selama proses belajar menagajar berlangsung.

Teknik analisis data yang digunakan dalam penelitian ini menggunakan analisis kualitatif. Analisis kualitatif digunakan untuk menganalisis seputar pembelajaran mahārat al-qiräà ah 2 dengan menggunakan strategi group investigation dengan bingkai pendekatan literasi kritis kepada mahasiswa semester 3 Jurusan Bahasa dan Sastra Arab. Langkah dalam menganalisis data yang telah dikumpulkan peneliti, yaitu dengan menggunakan metode deskriptif kualitatif analisis data Miles 
dan Huberman yang memiliki beberapa tahapan melakukan pengumpulan, mereduksi, men-display, dan analisis data. Data dikumpulkan, kemudian dilakukan reduksi dengan memilih dan memilah data. Data yang sesuai dengan penelitian ini, diambil, sementara yang tidak sesuai akan dibuang. Selanjutnya, data akan diklasifikasi berupa narasi, dan terakhir, dilakukan analisis.

\section{Hasil Penelitian}

Pembelajaran bahasa Arab selama ini sesuai dengan tujuan dalam pembelajaran keterampilan membaca (mahārat al-qirā'ah 2) di mana mahasiswa tidak hanya mampu membaca sesuai nậwu dan șaraf, tetapi juga mampu untuk memahami dan menganalisis teks dalam bentuk wacana sastra, wacana ilmiah, dan wacana jurnalistik yang baik dengan kritis. Berbagai jenis teks yang dipelajari atau yang digunakan dalam pembelajaran dapat diakses melalui jurnal, berita, melalui link yang berhubungan dengan bahasa Arab. Adapun proses pembelajarannya dimulai dengan pembagian dua kelompok atau lebih, kemudian dituntun untuk mengenal berbagai jenis teks sesuai dengan tema. Setelah itu, mahasiswa diminta untuk menganalisis unsur pembangun suatu wacana atau biasa disebut dengan $5 \mathrm{~W}+1 \mathrm{H}$ (what, who, where, when, why, dan how), kemudian melakukan scanning (mencari informasi khusus yang terdapat dalam teks), serta predicting (menebak makna berdasarkan konteks). Dalam pelaksanaannya, penerapan strategi group investigation dilakukan dalam beberapa tahapan, seperti yang tergambarkan dalam tabel berikut.

Tabel 1. Pelaksanaan penerapan strategi group investigation

\begin{tabular}{|c|c|c|}
\hline Tahapan & Peneliti & Mahasiswa \\
\hline 1 & $\begin{array}{l}\text { Pembagian Kelompok, terdiri } \\
\text { dari 5-6 orang }\end{array}$ & $\begin{array}{l}\text { Mempersiapkan diri dan melakukan } \\
\text { pembagian kelompok }\end{array}$ \\
\hline 2 & $\begin{array}{l}\text { Mengontrol kegiatan diskusi per } \\
\text { kelompok }\end{array}$ & $\begin{array}{l}\text { Melakukan diskusi kelompok sesuai } \\
\text { judulnya masing-masing. }\end{array}$ \\
\hline 3 & $\begin{array}{l}\text { Mengontrol waktu dan jalannya } \\
\text { presentasi }\end{array}$ & $\begin{array}{l}\text { Melakukan presentasi di depan kelas } \\
\text { terkait judul masing-masing dan } \\
\text { melakukan kegiatan tanya jawab sesuai } \\
\text { dengan waktu yang diberikan }\end{array}$ \\
\hline
\end{tabular}

Tahapan yang dilakukan dengan menggunakan strategi group investigation pada pembelajaran mahärat al-qirā'ab 2 dimulai dengan pembagian kelompok di mana setiap kelompok terdiri dari 5 sampai 6 mahasiswa. Setelah itu, mahasiswa diminta untuk memahami teks terkait dengan tema yang disediakan.Teks yang digunakan adalah teks yang sesuai dengan tema dalam perencanaan pembelajaran untuk mahārat al-qirē̄ah 2 mahasiswa semester 3 Jurusan Bahasa dan Sastra Arab, UIN Maulana Malik Ibrahim, Malang. Selanjutnya, mahasiswa diminta untuk memahami serta menganalisis teks dengan pendekatan literasi kritis. Pendekatan ini mendorong mahasiswa untuk berfikir kritis dan kreatif, dan menekankan pemahaman terhadap isi bacaan yang dapat dibentuk melalui analisis aspek secara tekstual dan kontekstual, serta mengedepankan keadilan sosial. Sebelum melakukan presentasi, terlebih dahulu mahasiswa mengumpulkan tugas kelompok. Kemudian, mahasiswa memperesentasikan hasil diskusi kelompok di depan kelas, serta melakukan kegiatan tanya jawab. 
Hasil yang dicapai dalam pembelajaran melalui strategi ini adalah mahasiswa banyak yang ikut berpartisipasi aktif dalam pembelajaran mahārat al-qirāah 2 ini, berani mengungkapkan pemikirannya di depan kelas, dan mampu berfikir kritis melalui diskusi bersama. Ini juga didukung dengan data wawancara yang dilakukan kepada mahasiswa terkait penggunaan strategi ini, di antaranya (S1) mengatakan bahwa "dengan menggunakan strategi ini dapat membuat suasana tidak menegangkan dan dapat diterima”; (S2): "metode pengajarannya membuat suasana kelas fun, asik, dan seru, santai, tapi serius”; dan (S3): “menyenangkan tapi kadang terburu-buru”. Sementara itu, kendala yang dihadapi peneliti dalam menggunakan strategi group investigation ini adalah komitmen terhadap waktu yang diberikan pada setiap kelompok. Sebagian kelompok tidak menyelesaikan diskusi dengan tepat waktu sehingga peneliti harus memberikan tambahan waktu. Dampaknya, ketika presentasi dan melakukan kegiatan interaktif, kesannya terburu-buru. Oleh karena itu, dalam hal ini solusi yang diberikan adalah peneliti harus lebih ekstra mengontrol proses diskusi serta komitmen terhadap manajemen waktu.

\section{Pembahasan}

Dari data yang ada, penelitian dengan menggunakan strategi group investigation mampu membuat suasana pembelajaran lebih interaktif, dan dapat merealisasikan tujuan dari mahārat al-qirāà 2 , yaitu untuk memperoleh dan memahami informasi (Hermawan, 2013). Selain tujuan tersebut, jika disesuaikan dengan tingkatan jenjang pendidikan, maka dibutuhkan keterampilan lebih dalam memahami sebuah bacaan, seperti halnya dalam penelitian ini yang dilakukan di jenjang perguruan tinggi. Peserta didik berada pada tingkatan membaca kreatif dan kritis. Hal ini didukung oleh pernyataan Laili Fitriani (2019), di jenjang perguruan tinggi, pembelajaran mahārat al-qirààh masuk pada ruang lingkup membaca pemahaman (comprehension skills) dan membaca kritis (critical reading). Dalam kemampuan membaca (mahārat al-qirā'ah), selain mampu menguasai atau membaca teks bahasa Arab sesuai dengan naḅwu dan șaraf, juga mampu menghubungkannya atau menerapkannya dengan pengetahuan yang ada. Dengan demikian, pendidik dituntut untuk mampu mengemas sebuah proses pembelajaran sedemikian rupa agar dapat merealisasikan tujuan yang diinginkan.

Strategi yang digunakan dalam pembelajaran harus disesuaikan dengan beberapa aspek, di antaranya penggunaan strategi itu sendiri, jumlah dan karakteristik peserta didik, serta penggunaan waktu. Menurut Satutik Rahayu (2015), dosen sebagai seorang pendidik juga pengajar harus mampu mengelola kelas dengan baik. Dibutuhkan kreatifitas pemilihan model, strategi, metode, dalam pembelajaran, selain juga harus disesuaikan dengan karakteristik siswa, banyaknya siswa, serta materi yang akan diajarkan. Dengan begitu, dosen mampu membantu mahasiswa belajar secara mandiri, aktif dan efektif. Dalam penelitian ini, setelah melakukan observasi awal terkait dengan karakteristik peserta didik yang cenderung pasif ketika ditanya serta kurangnya rangsangan untuk menjawab pertanyaan, maka dari itu peneliti mencoba untuk menawarkan strategi ini dengan tujuan agar mampu mendorong setiap mahasiswa memberanikan diri menyampaikan pendapatnya. Sesuai dengan teori yang ada, pembelajaran dengan menggunakan startegi ini dapat mendorong dan memacu mahasiswa atau pembelajar untuk berpikir dalam kelompok secara kritis, kreatif, serta analitis (Aini et al, 2018, p. 19).

Penerapan strategi group investigation dalam penelitian ini dapat meningkatkan pemahaman mahasiswa secara mandiri untuk menyelidiki masalah yang ada secara kritis, dan mampu 
menemukan konsep melalui kerjasama. Hal tersebut sesuai dengan pendapat Zahratul Aini, dkk (2018), strategi ini mampu memacu peserta didik lebih berfikir kritis, kreatif, dan analitis. Selanjutnya, mahasiswa diminta untuk mempresentasikan hasil temuannya di depan kelas, dan melakukan tanya jawab. Dengan demikian, melalui presentasi mahasiswa saling berbagi informasi terkait judul atau tema yang diberikan. Hal ini seuai dengan pendapat Rusman (2010), setiap kelompok mempresentasikan laporannya dengan tujuan untuk berkolaborasi atau bekerjasama dalam mentransfer terkait temuan kelompok masing-masing. Akan tetapi, dalam penelitian ini kendala yang peneliti alami adalah ketika pengkondisian kelas dalam mengatur waktu. Banyak kelompok yang belum menyelesaikan sesuai dengan waktu yang diberikan sehingga meminta tambahan waktu. Ini disebabkan karena kurangnya mufradāt atau kosakata dalam menghubungkan teks secara kontekstual. Sementara itu, dalam penelitian-penelitian sebelumnya belum ada yang menjelaskan atau memaparkan terkait kendala dalam penggunaan strategi ini.

\section{Simpulan}

Dalam proses pembelajaran bahasa Arab, khususnya dalam pembelajaran mahārat al-qirā̄ah 2, sangat dibutuhkan kreativitas dan inovasi dari para pendidik untuk meningkatkan kemampuan berfikir di berbagai jenjang pendidikan. Selain itu, juga untuk menganalisis kebutuhan yang sesuai dengan tujuan pembelajaran, sehingga mampu menemukan solusi yang tepat dalam mengatasi masalah yang ada. Penggunaan strategi group investigation cukup efektif dalam pembelajaran keterampilan membaca untuk tingkatan mahasiswa. Pembelajaran yang berbasis kelompok ini mendorong mahasiswa untuk aktif dan bekerjasama dalam menganalisis sebuah wacana melalui kerangka pendekatan literasi kritis. Meskipun banyak mahasiswa yang aktif dalam kegiatan diskusi, namun terkadang strategi memakan banyak waktu jika tidak konsisten dengan waktu yang diberikan. Harapan kedepannya, semoga semakin banyak kreatifitas dan inovasi dari pendidik terutama dalam proses belajar dan mengajar bahasa Arab lebih khususnya dalam keterampilan membaca di tingkat universitas baik melalui strategi, pendekatan, media, dan lain sebagainya. Selain dari penguasaan unsur dan keterampilan bahasa Arab, juga mendorong agar pembelajarannya menyenangkan dan tidak membosankan, serta membangun partisipasi aktif mahasiswa.

\section{Daftar Rujukan}

Adia, K. (2019). Implementasi model pembelajaran kooperatif tipe group investigation untuk meningkatkan hasil belajar pada mata pelajaran simulasi digital. Jurnal Pedagogi dan Pembelajaran, 2(1), 72-83. doi:10.23887/jp2.v2i1.17612

Aini, Z., Ramdani, A., \& Raksun, A. (2018). Perbedaan penguasaan konsep Biologi dan kemampuan berfikir kritis siswa kelas $\mathrm{X}$ pada penerapan model pembelajaran kooperatif tipe group investigation dan guided inquiry di MAN 1 Praya. J. Pijar MIPA, 13(1), 19-23. doi:10.29303/jpm.v13i1.466

Asbullah, L. H., Aladdin, A., Lubis, M. A., \& Sahrim, M. (2019). Strategi pembelajaran kolokasi bahasa Arab dalam kalangan pelajar University Awam Malaysia. Journal of Language Studies, 19(2), 139-159. doi:10.17576/gema-2019-1902-09 
'Abd al-Majīd, H. M. (2005). Anshițah wa-mahārāt al-qirā'ab wa-al-istinkār fì al-madrasatayn alibtidā'zyah wa-al-i'dādìyah. Amman: Dār Șafā'.

Djamarah, S. B., \& Zain, A. (2006). Strategi belajar mengajar. Jakarta: Rineka Cipta.

Fitriani, L. (2018). Pengembangan bahan ajar Qira'ah berbasis karakter di perguruan tinggi. Jurnal An-Nabighoh, 20(01), 1-18. doi:10.32332/an-nabighoh.v20i01.1130

Fitriani, L. (2019). Ta'līm mahārat al-qirā’ah 'alá asās al-qirā’ah al-nāqidah bi-al-taṭbīq 'alá țalabat qism al-lughah al-'Arabīyah wa-adabihā bi-Jāmi'‘at Mawlānā Mālik Ibrāhim al-Islāmīyah alHukūmīyah Malang. In I. Asrori et al (Ed.), Ta'zìz dawr al-lughah al-'Arabiyah fì al-hadèrah wa-al-tarbiyah: Bayn al-wāqi' wa-al-ma'mūl. Prosiding Pertemuan Ilmiah Internasional Bahasa Arab PINBA IMLA XII. (pp. 355-366). Bandung, Indonesia.

Hakim, M. D., Mathoriyah, L., \& Rahmawati, R. D. (2018). Efektifitas strategi group investigation untuk meningkatkan kemampuan siswa dalam menerjemahkan bahasa Arab ke bahasa Indonesia. Journal of Educatio and Management Studies, 1(2), 81-84. Retrieved from https://ojs.unwaha.ac.id/index.php/joems/article/view/49/34

Hermawan, A. (2013). Metodologi pembelajaran bahasa Arab. Bandung: PT. Remaja Rosdakarya.

Hidayah, B. (2019). Peningkatan kemampuan membaca kitab kuning melalui pembelajaran Arab pegon. Jurnal Ilmu Pendidikan, 3(1), 102-119.

Retrieved from http://jurnal.iaibafa.ac.id/index.php/murobbi/article/view/194

Marselina, S. (2018). Peningkatan keterampilan menulis karya ilmiah melalui strategi belajar kooperatif tipe group investigation siswa kelas XI MAN Kota Sungai Penuh. Pentas: Jurnal Ilmiah Pendidikan Babasa dan Sastra Indonesia, 4(1), 14-21. Retrieved from http://ejurnal.unisda.ac.id/index.php/pentas/article/view/816

Mustofa, S. (2014). Strategi pembelajaran bahasa Arab. Malang: Dream Litera Buana.

Nisa, N. N., Firdaus, F., Wardani, N. C. (2019). Modifikasi metode qawa’id wa tarjamah dengan strategi contextual teaching and learning (CTL) dalam pembelajaran maharah kitabah. In Inovasi Media Pembelajaran Babasa, Sastra, dan Budaya Arab. Seminar Nasional Bahasa Arab Mahasiswa III (pp. 87-102). HMJ Jurusan Sastra Arab Fakultas Sastra Universitas Negeri Malang, Indonesia.

Nopitaningrum, D. (2019). Membaca kritis (Paper, Universitas Sebelas Maret Surakarta). Retrieved from https://osf.io/preprints/inarxiv/a2qgy/

Poerwadarminta, W. J. S. (1980). Kamus umum bahasa Indonesia. Jakarta: Balai Pustaka.

Putri, D. (2018). Improving news writing skill by using cooperative type group investigation strategy. Curricula: Journal of Teaching and Learning, 3(2), 78-86. doi:10.22216/jcc.2018.v3i2.2878

Rahman, A. A. (2017). Kerterampilan membaca dan teknik pengembangannya dalam pembelajaran bahasa Arab. Jurnal Diwan, 3(2), 155-169. Retrieved from http://journal.uinalauddin.ac.id/index.php/diwan/article/view/4602

Rahayu, S. (2015). Model simulasi dalam mata kuliah Strategi Pembelajaran Fisika. Jurnal Pendidikan Fisika dan Teknologi, 1(2), 118-122. doi:10.29303/jpft.v1i2.246

Rusman. (2010). Model-model pembelajaran: Mengembangkan profesionalisme guru (2 $2^{\text {th }}$ ed.). Jakarta: Raja Grafindo Persada.

Sakinah AR, N., \& Purwanto. (2019). Pengaruh pembelajaran group investigation dengan metode everyone is a teacher here terhadap hasil belajar siswa di SMAN 21 Medan. Jurnal Ikatan Alumni Fisika Universitas Negeri Medan, 5(2), 1-6. 
Retrieved from https://jurnal.unimed.ac.id/2012/index.php/jiaf/article/view/12550

Sharan, S., \& Shachar, H. (1988). Language and learning in the cooperative classroom. New York: Springer, Verlag.

Suja'i. (2008). Inovasi pembelajaran bahasa Arab: Strategi dan metode pengembangan kompetensi. Semarang: Walisongo Press

Syuhaimi, R. (2019). Penerapan model pembelajaran group investigation dapat meningkatkan minat dan keterampilan reading comprehension peserta didik kelas IXA di Madrasah Tsanawiyah Negeri 3 Kampar. Jurnal Pendidikan Tambusai, 3(1), 549-560. Retrieved from https://jptam.org/index.php/jptam/article/view/244 